\title{
WHERE DOES OUR INTEREST IN VENEZUELA COME FROM?
}

Until recently, very few people in the world heard of Venezuela. It was known that the seventh largest country in Latin America had a relatively well-established democracy, was friendly to immigrants, and rich in natural resources. And that was basically it since the beginning of 1958 and the fall of the dictatorship of Marcos Pérez Jiménez, when Venezuela entered the path to democratic development, it has not fed the world press with any sensational news. From a detached, European perspective, with its often distorted Euro-centric point of view, there has been nothing special about Venezuela to distinguish it from among other Latin American countries.

Venezuelans, remembering Pérez Jiménez's authoritarian government, which - as it seemed - was the last in the long line of classic military dictators (referred to as caudillos), and dating back to the first half of the nineteenth century, still differ in their assessment of that period. However, the dominant opinion is that, despite the undemocratic and repressive government, Venezuela had made a big leap forward in those days. Large-scale public works and high oil prices on the world markets helped create a modern (by the standards of the times) road infrastructure. Tunnels were constructed in the mountains surrounding Caracas, which allowed highways to connect the capital with the interior of the country. Hydroelectric plants were built. Mining and metallurgical industry flourished. Caracas became a chic South American capital city, vibrant and boasting the ultra-modern communication and transport solutions, often adopted from the U.S. The country attracted immigrants from Europe.

After the fall of Pérez Jiménez's dictatorship, Venezuela, which remained in the U.S. sphere of political dominance, did not attract much interest. The world was in the grip of the Cold War at the time, and its attention was attracted by countries that formed the new 'Cold War fronts', such as Cuba, where Fidel Castro and his revolution triumphed on 1st January 1959. It is no wonder that, at the beginning of the 1960's, the leftist guerrilla activity in Venezuela gained significant publicity, but mostly as an attempt to 
spread the Cuban revolution. It ended in failure, and interest in Venezuela subsided. The country, dependent upon oil revenues, lived its own life, which was determined by fuel prices on the world markets. High prices in the 1970's ensured an economic boom, but the trend reversed in the 1980's and 1990's. Venezuela had no means to finance its development. This was particularly experienced by the poorest circles of society. Poverty spread.

On the wave of mass discontent riots broke out on 27th February 1989, the participants of which went on a rampage of violence, attacking civilians and police forces alike, looting, pillaging, and plundering shops. The government of President Carlos Andrés Pérez sent troops to suppress the riots in Caracas and other cities. Hundreds of people were killed, mostly in the capital; hence, the social rebellion is often referred to as the "Caracazo".

\section{THE AGE OF CHÁVEZ}

Venezuela hit the spotlights again in 1992, when an unknown paratrooper lieutenant colonel, Hugo Rafael Chávez Frías, together with a group of other military officers, made a failed coup attempt. Later, after his release from prison in 1994, Chávez and his socialist Fifth Republic Movement grew in strength, and he finally won the presidential elections at the end of 1998. The reasons for his rise to power can be traced back to the complete embarrassment of the current political elites, the deepening poverty of a significant part of society, and the lack of funds for the country's development due to low oil prices on world markets. In the initial phase, Hugo Chávez was supported not only by the poorest, but also by much of the middle and upper classes, disappointed in the actions of the traditional political parties: $\mathrm{AD}$ (Democratic Action) and COPEI (Christian Democratic Party). It was known that Hugo Chávez's mentor was the Cuban leader Fidel Castro, but no-one suspected that the traditionally pro-American country with full-blown consumerism would take a path of development similar to that of communist Cuba. No-one suspected that Chávez's victory in the elections of 1998 would initiate a 14-year period of his almost uninterrupted rule.

Chávez withstood the test of time. The general strike that paralyzed the oil industry - the main source of income for the state - which lasted for several months between 2001 and 2002, did not manage to break him. The attempt to overthrow his government in a coup, carried out on 11th April 2002, failed. Two days after being removed from power, Chávez returned triumphantly to the Presidential Palace. His rule gained democratic legitimacy through various elections (presidential, parliamentary, local government), or referendums (constitutional and appeals), which were held at least once a year. The ruling camp emerged victorious from almost every one of those, except only the one constitutional referendum in 2007, when Chávez failed to push through constitutional changes, most of which, however, he introduced later through a "back door". The opposition repeatedly accused him of electoral fraud. However, the allegations were never confirmed by independent observers. In 2005, after boycotting the parlia- 
mentary elections, the opposition lost its parliamentary representation. A few years later, however, it managed to regroup, and - united as the Democratic Unity Table regained significant parliamentary representation, gaining the power to block further attempts at changing the Constitution.

Chávez successfully led to the unification of almost all political parties that sympathized with his agenda. In 2008, the founding congress of the United Socialist Party of Venezuela (PSUV) was held. In the presidential elections conducted on 7th October 2012, Hugo Chávez - the leader of PSUV - secured his second re-election and a mandate for the next six years (2013-2019), with almost 11-percent advantage over the opposition candidate, a politician of Polish origin, Henrique Capriles Radonski. Thus, voters clearly opted in favor of maintaining the status quo. The ruling camp was successful also in the state governor elections that took place two months afterwards. Almost all the candidates nominated by the bedridden President won in their respective states. The government "took back" four states, including two traditional strongholds of the opposition: Zulia and Táchira. The opponents of the government retained power in only three of the 23 states of Venezuela: Amazonas, Lara, and Miranda - where Radonski returned as governor. However, the re-inauguration of Chávez as President never came to pass, prevented by his critical condition. After a year-and-a-half battle with cancer and four operations performed in Cuba, the leader of the ruling camp - undefeated in several election campaigns - expired on 5th March 2013. However, he did manage to anoint Vice President Nicolás Maduro Moros as his successor.

The very date of the presidential elections - deliberately set to take place not too long after Chávez's death - put Maduro in a privileged position. Maduro proclaimed himself to be "Chávez's apostle" and called for the people to ensure the continued rule of the nation's commander in chief (Spanish: "comandante en jefe"). He revealed that he had maintained spiritual contact with the dead "comandante", who appeared to him as a little bird. Maduro also accused the U.S. (the country that - according to the Chavista rhetoric - is the embodiment of the great Satan) of infecting the "comandante en jefe" with cancer. During the election campaign, he made frequent references to religious symbolism, spiritualism, and the belief in the supernatural - all of which is quite close to the hearts of Venezuelans. Similar elements appeared earlier in the rhetoric of Chávez, who wanted to be perceived as a new Christ for the nation and an incarnation of Latin America's great Venezuelan 'Libertador' - Simon Bolivar.

His opponent - once again running for presidency - was Henrique Capriles Radonski, a moderate who leaned towards the center-left wing, although his party - Justice First (Primero Justicia) - was sometimes referred to as right-wing liberal. Radonski himself became known as a supporter of the Brazilian development model, favoring a free-market economy with strong protective measures for the poor, established through the implementation of national social assistance programs. He made frequent references to the political left, represented by the former President of Brazil, Luiz Inácio Lula da Silva; he sharply criticized the ruling camp for its ineffective and bad management of the economy and the increase in armed crime on an unprecedented scale. 
According to the official results, Maduro defeated Radonski by approximately 235 thousand votes (1.5\% difference) in the presidential elections held on 14th April 2013. However, according to Radonski (who had not contested the results of previous elections), this time the ruling camp committed a fraud on a large scale, which completely distorted the results. The opposition did not accept Maduro's victory, demanding the recount of all votes cast. The Supreme Court delayed making a decision on the matter for several weeks, and it seemed rather unlikely that the opposition would be able to change the outcome of the elections; it was quite clear that in the short time that had passed since the death of Chávez there was a rapid increase in the number of opponents of the "Bolivarian Revolution". The deepening polarization of society coincided with increasing economic problems. The government, which took control of a large portion of the economy and trade, had more and more difficulties in obtaining supplies of basic goods.

\section{PRESCRIPTION POPULISM}

How to explain the fact that an ahistorical, as it might seem, project of the "Bolivarian Revolution", inspired by the Cuban example, or the so-called Twenty-first Century Socialism, retained ardent supporters for such a long time?

The support of more than $50 \%$ of the people in all of Chávez's 'electoral popularity tests' testified to the fact that the majority of Venezuelans assessed his rule positively, or at the very least did not see a possible alternative. The pursuit of the so-called participatory democracy by creating new, bottom-up structures of local government (municipal councils, communes, communal cities, etc.), parallel to the existing structures, the promotion of an economic system based on the principle of social solidarity, encouraging people to take justice into their own hands - gave millions of excluded Venezuelans a sense that their problems would not be swept under the carpet - that someone was finally taking them into account. They also recovered the sense of citizenship and national identity. Revenue generated by the increase in oil prices allowed the government to spend heavily on social assistance programs. This contributed to improving the living conditions of the poor, or - at the very least - gave them hope for a better tomorrow. On the other hand, a new, heavily corrupt ruling elite (government officials, businessmen linked to the government's agenda) was formed, and they found the current system highly convenient. What worked in their favor was the strict state control over the economy, fixed prices, and the artificially-sustained undervalued dollar, which gave great opportunities for speculation.

The constant juxtaposition of the rich and the poor, the continuous attacks on the "oligarchy", the expropriation and nationalization of property - resulted in a significant polarization of society. The encouragement for the people to take justice into their own hands was probably one of the reasons for the increase (on an unprecedented scale) of armed crime. The doubts of opposition and a portion of observers were also raised by the achievements of Chávez's government in the field of improving the living con- 
ditions of the poorest Venezuelans. His critics suggested that a different government would probably be able to better use the excellent economic situation on the international oil markets, and pointed out the fact that the actions taken were only provisional and populist in nature, and did not contribute to structural improvements. In the opinion of Chávez's opponents, pumping money into short-term social assistance programs became the only solution to improve the lives of the poorest members of society. However, it is certain that future Venezuelan politicians will not be able to ignore the problem of poverty and exclusion, and the fact can be attributed to Chávez.

Contrary to previous official announcements, there was no diversification of Venezuela's economy, which became even more dependent on oil ( $90 \%$ of export earnings, about 30\% of the GDP) and on imports of most basic foodstuffs. The "Simón Bolívar" National Development Plan, implemented with an iron hand in the years 2007 2013, has led to changes in the ownership structure, whose purpose was to drastically reduce private property. Currently, one-third of Venezuela's economy is managed by state-owned enterprises, one-third belongs to socialist co-operatives, and the rest are privately-owned companies. Venezuela's foreign debt rose from $\$ 44.8$ billion in 2006 to $\$ 149$ billion at the end of 2012, and the production base also shrank. The opposition warns that the possible collapse of oil prices threatens to render Venezuela insolvent.

But the "Bolivarian Revolution" project needs to be perceived in the context of the Latin American reality. It was born from the experiences of the 1980's, often referred to in Latin America as the "lost decade". For many countries of the region, those years brought an unprecedented increase in foreign debt, hyperinflation, a huge fiscal deficit, the inhibition of economic growth, and deepening poverty. Neoliberal economic moves that were supposed to counteract the crisis in the region contributed to an even greater gap between the richest and the poorest, and deepened the social contrasts. Chávez's project coincided with the movement of the left-wing groups, criticizing the influence of neoliberalism in Latin America. It was inaugurated in 1990, during the Foro de São Paulo. In the first decade of this century, after coming to power of leftist politicians in many Latin American countries, the Foro de São Paulo was attended by governmental envoys or leaders of the governments of over a dozen Latin American countries, such as Brazil, Venezuela, Bolivia, Ecuador, Honduras, and Cuba - to name only a few. Hugo Chávez, who defended those excluded, probably felt he was not alone in his struggle when, in 2009, the entire world was shaken by the financial crisis, and in distant Europe the Indignants Movement grew in strength, challenging the strategy for dealing with the crisis.

\section{VENEZUELA - A LEADING REGIONAL PLAYER}

However, charismatic Chávez was able to restore Venezuela to an important place on the international arena. In the first decade of the twenty-first century, the country has become an important point of reference in discussions about Latin America, and has started to hit the headlines of the world's leading newspapers. 
Under President Chávez, Venezuela began to play a leadership role in the processes of regional integration, which flourished in the first decade of this century. Although Brazil moved to the fore as the rising international power, increasingly aspiring to the role of a global player, Venezuela followed closely, with its main goals being the exclusion of the USA from the process of regional integration, and the promotion of the "21st Century Socialism". By opting for the inclusion in the regional economic relations of the principles of complementarity and social justice, President Chávez denounced the "wild" capitalism and imperialism represented - according to him - by the USA. Using the revenue generated thanks to the high prices of oil, he strove to increase the importance of Venezuela in the region and limit US influence.

During the successive Summits of the Americas, held since 1994 under the auspices of the Organization of American States (OAS), the United States advocated the project for the creation of the Free Trade Area of the Americas (FTAA, Spanish: ALCA). However, the project was finally dropped during the Fourth Summit of the Americas, which took place in November 2005 in Mar del Plata, Argentina. The diplomatic failure of the US was largely brought about by Venezuela and the Mercosur (Southern Common Market) member states, namely: Brazil, Argentina, Uruguay, and Paraguay, which substantiated their objection quoting the lack of symmetry between the economies of the opulent North America and the remainder of the Americas.

In opposition to the project of the U.S., Venezuela and Cuba brought to life the Bolivarian Alternative for the Peoples of Our America, later renamed "the Bolivarian Alliance for the Peoples of Our America" (ALBA). In subsequent years, ALBA was joined by Bolivia, Nicaragua, the Commonwealth of Dominica, Honduras, Ecuador, St. Vincent and the Grenadines, as well as Antigua and Barbuda. This largely political mechanism of integration was defined by the opposition of the united front of the developing countries against the principles of the free market. In 2005, Venezuela launched the Petrocaribe oil alliance, which was joined by 15 Caribbean and Central American states, whose motivation was generally more pragmatic than ideological. Under this Alliance, Venezuela granted those states the option to purchase oil on preferential conditions (lower prices than those of the world market, convenient, multiyear loan repayment forms, etc.). In the case of ALBA, and to an even greater extent in the case of Petrocaribe, Venezuela was solidifying its influence using the so-called oil diplomacy.

Due to its strategic geographical location, Venezuela is a bridge between South America and the Caribbean. This location, in conjunction with oil diplomacy, ensured Venezuela's privileged relations with the Caribbean states, and strengthened its position on the international arena.

On the initiative of Brazil, the first Meeting of South American Presidents was called in the capital city of Brasilia in 2000, which laid the foundations for the South American Community of Nations, formed in 2004. The leaders of 12 South American countries, participating in the Summit held in 2007 on the Venezuelan island of Margarita, decided that this bloc of regional political and economic integration would be renamed as the Union of South American Nations (UNASUR). It was yet another 
regional grouping where Venezuela - under the leadership of Chávez - wanted to play a leadership role.

Driven by political considerations more than the economic ones, Venezuela withdrew from the Andean Community of Nations (CAN) in 2006, and joined the MERCOSUR. The pretext for the withdrawal from CAN was provided when Peru and Colombia entered into free trade agreements with the U.S.A. According to the Venezuelan opposition and independent observers, due to the complementarity of the economies and easy transportation on land, the membership in the CAN block (whose members include Colombia, Peru, Bolivia and Ecuador) was much more natural and beneficial for Venezuela. By entering the MERCOSUR, Venezuela received an additional platform for co-operation with the leading players in South America: Brazil and Argentina. However, the other members of the MERCOSUR will certainly benefit more from the fact that Venezuela - rich in oil resources - joined their ranks.

In 2010, a decision was made to establish the Community of Latin American and Caribbean States (CELAC), and the first summit of the bloc that brought together 33 countries, including Cuba, took place in December 2011 in Caracas. CELAC is the successor of the Rio Group (established in 1986) and the Latin American and Caribbean Summit on Integration and Development (CALC, since 2008), which constituted the main platforms for political dialogue. It is the first distinct subcontinental bloc without the participation of the U.S. or Canada. The intention of Chávez was that CELAC would replace the Washington-dominated Organization of American States.

In addition to Latin America, Venezuela sought alliances and cooperation with the countries which - according to Chávez's government - share its anti-imperialist agenda and the belief in the necessity of building a multipolar world and reducing the U.S. influence. The list of these countries included Putin's Russia, Lukashenka's Belarus, Ahmadinejad's Iran, al-Assad's Syria, and Libya (prior to the death of Muammar Gaddafi). Due to the economic potential and political power of China, Venezuela also strengthened its relations with the Asian super-power.

\section{WHAT AFTER CHÁVEZ?}

Without charismatic Chávez, Venezuela is no longer likely to play such a big role in the international arena. Maduro does not move the masses like his predecessor. The option of using oil diplomacy remains his advantage in foreign relations - provided the persistence of high oil prices on world markets.

It is expected that changes on the Venezuelan political scene will speed up. Cracks begin to appear in the previously seemingly-monolithic ruling camp, which may lead to fragmentation in the foreseeable future. Various warring factions within it may come to the fore. The main dividing line can be seen between the civilian politicians fraction with Maduro at its helm, and military men (those in uniforms as well as those wearing civilian apparel), who dominated the state apparatus. Also, such influential groups as the representatives of the national oil sector will pursue their own interests and 
attempt to secure as much power as possible. Likewise, entrepreneurs who made fortunes thanks to government contracts and ties with the authorities will not give up power and privileges easily. The problem of corruption will most probably exacerbate during the twilight (as it appears) stages of the revolution. The result of the recent presidential elections proved that the ruling camp has at least as many opponents as supporters, and it is difficult to believe that such a stalemate can continue for a long time.

The Chávez Era will gradually fade away, even though it is possible for the "Bolivarian Revolution" to be kept alive a little longer. Unfortunately, there is no guarantee that the transformation will be free from shake-ups and violence. There are still many challenges before Venezuela - now more than ever dependent on the income from oil sale, and experiencing numerous unresolved social problems. Perhaps the most important of these is the need to create a solid foundation for a diversified economy and to increase its competitiveness, which has certainly not been contributed to by expropriation and increase in the state's control over the economy. Efforts are necessary for Venezuela rich in natural resources and having the world's largest certified deposits of oil - to fully utilize its potential for sustainable improvement of the living conditions of the whole population, including the poorest.

The opposition accused Chávez of authoritarian rule and limiting the independence of the three branches of state power by subordinating to himself the judiciary and the legislature. In the economic sphere, Venezuelan revolutionary model of development invariably raises associations with Cuba - the country which was led to the edge of an economic abyss by its revolution. As with other such experiments, the utopian project of the "21st Century Socialism" is doomed to fail.

\section{BLOOD TIES WITH EUROPE AND OTHER CONTINENTS}

Venezuela is a conglomeration of different nationalities, races, and cultures. It is one of the countries with the greatest ethnic diversity, which is the result of the mixing of the indigenous people (Indian), Europeans, and Africans. According to the last census, half of the population are mestizos, resulting from the mix of Europeans, Africans, and Indians. The white population, whose origins can be traced back to Europe or the Middle East, amounts to $42 \%$. Black or mulatto population constitutes 3.5\%, Indians $-2.7 \%$ and the representatives of other races, mostly Asians - $1.1 \%$. After the mass import of African slaves during the colonial period, the further, longer, voluntary migration waves were associated with dramatic, world-shaking events: World War I and II, the Cold War, as well as the Spanish Civil War, and the discovery of oil deposits in Venezuela in the early twentieth century.

From the European perspective, Venezuela is important because of its direct links with the "Old Continent". Several million Venezuelans, belonging to the migrant communities of Spaniards, Italians, and the Portuguese (Venezuela has one of the largest Portuguese migrant communities outside Portugal), have European roots, often in the first or second generation. Hundreds of thousands of Venezuelans have EU passports. 
In Venezuela there are newspapers published in Portuguese and Italian. No wonder that in Caracas and other Venezuelan cities one can easily find excellent restaurants serving the Mediterranean cuisine. Most of them belong to the Portuguese, who seem to be the leaders of the local restaurateurs' community. The bakeries (panderias) - where one can buy not only delicious bread and pastries, but also a lot of basic and deli foods - belong to them almost exclusively. They also offer appetizers, sandwiches, and some of them serve full dinner dishes.

Spaniards, Italians, and the Portuguese have their own sports clubs, many of which have been engaged in cultural activities and enjoy a well-deserved reputation. When football championships are held in remote Europe, with the national teams of Spain, Italy, and Portugal in participation, Caracas becomes an arena of a great football fiesta. Thousands of fans watch the games on large screens, set in the central areas of the city. The cars in the streets are decorated with flags of European countries, and drivers use horns liberally to proclaim the victories of "their" teams. One can almost get the impression that the UEFA European Football Championships cause greater excitement in Venezuela than in Europe. But the children of European immigrants today feel mainly Venezuelan, and whenever European teams face Venezuela, they cheer for both sides because you can feel both Venezuelan and European at the same time.

After World War II, many of the Jews who flooded mainly from Central Europe (including Poland) settled in Venezuela. It was here that they sought refuge from the Holocaust, and found a new home. A significant part of the Jewish Community in Venezuela is made up of Polish Jews.

Serving from October 2007 to July 2012 as the Polish Ambassador to Venezuela, additionally accredited to 8 countries of the Caribbean, I had the opportunity to establish closer contacts with the local Polish community, which - it is estimated -consists of 3-4 thousand people. Among them are many prominent representatives of science, culture and the arts, as well as business and the media, such as the world-renowned archaeologists - Doctors Andrzej and Magdalena Antczak, Nina Nowak - the creator of the ballet school, architect Lech Adamowicz, musician and composer - Gerardo Gerulewicz, painter and artist - Leonardo Gerulewicz, and Ana Cepinska - Miss World Venezuela 1996. Those who openly speak of their Polish descent include also: Miranda state governor and former opposition candidate in the presidential election - Henrique Capriles Radonski, the guru of the Venezuelan opposition - Teodoro Petkoff, a famous sculptor - Harry Abend, a prominent writer - Alberto José Barrera Tyszka, and a wellknown TV and radio journalist - Roman Lozinski. The list is very long and it would be difficult to mention all the names here.

Venezuela also has direct connections with the Middle East - hundreds of thousands of Venezuelans have Syrian and Lebanese roots. These communities produce many government officials, as well as eminent men of science and culture. Hundreds of thousands of Colombian refugees sought shelter in Venezuela during the armed conflict in Colombia. It is estimated that this community now numbers about 3-4 million people, most of whom have Venezuelan citizenship. Immigrants from Peru, Uruguay, and other Latin American and Caribbean countries have also flooded into Venezuela. 
The number of indigenous Indian population is estimated at 700,000 people. Almost 40 indigenous languages have been classified, although some of them are already used by very few groups - and may soon disappear entirely. The largest language groups include the Wayuu (about 120 thousand people), the Pemon (30 thousand), and the Warao (18 thousand). The constitution provides that Spanish is the official language, but Indian languages are also recognized as official, whenever they are spoken by indigenous people, and as such are considered to be the cultural heritage of Venezuela.

The mixture of races, ethnic groups and nationalities determines the cultural wealth of Venezuela, which is reflected in the cuisine, dance, music, and the lexical layer of the variety of the Spanish language spoken here. The cultural and religious syncretism constitutes an important part of the cultural identity of Venezuelans. It would be difficult to talk about Venezuela not knowing the cult of the Queen-Goddess María Lionza, considered to be the mother behind the mixing of races: white Spaniards, black Africans, and Indians. The cult is a blend of Catholic rituals and beliefs, Indian spiritualism, aspects of Santeria, Voodoo, and mystical elements. The main celebrations in the state of Yaracuy are held on 12th October. Thousands of pilgrims arrive there at that time. But the worshippers of María Lionza can be found throughout Venezuela and abroad, including such times as the so-called Semana Santa - the Easter period. An interesting ritual, practiced on Corpus Christi in San Francisco de Yare in Miranda State (near Caracas), is the celebration of the "Dancing Devils of Yare". The entire town participates. The Sociedades del Santísimo (Societies of the Holiest) are in charge of the celebration. Their origins can be traced back to the 18 th century, making them the oldest brotherhood of the American continent. People dressed up as devils, wearing red capes and grotesque masks, bang sticks on the church door, then dance in the streets of the mountain town. The fiesta lasts for a couple of days, and the town prepares for it all year. Another example of cultural syncretism is the Carnival in El Callao in Bolivar State, where tens of thousands of people come every year. The cue to start the Carnival is given by the black "madamas", wearing turbans on their heads and numerous necklaces. Then, the Carnival Parade is held, to culminate with night-long dancing in the streets. It is interesting that there are no generational divisions. Everyone takes part in the festivities: parents, children, and grandchildren. It is a tradition that is over 150 years old. It was derived from the times of the local gold rush of 1853 , when black slaves were brought there from the French-speaking and English-speaking Caribbean islands, including nearby Trinidad and Tobago. To this day, people living here use English and French words, and the texts accompanying the Carnival of Calypso music are a mixture of English and Spanish.

\section{VENEZUELA'S POTENTIAL}

Venezuela, covering an area of over 916 thousand square kilometers, with a population of 29 million inhabitants, is the fifth largest economy in Latin America. It has the world's largest officially certified oil reserves (more than Saudi Arabia), though the 
type of oil extracted here requires advanced processing technology. It also has deposits of natural gas, coal, iron ore, aluminum, bauxite, gold, diamonds, uranium, and other minerals. The Orinoco River basin provides Venezuela with abundant hydroelectric resources.

Located on the Atlantic Ocean and the Caribbean Sea, Venezuela has an exceptionally varied coastline with many islands and fabulous archipelagos, such as Los Roques. It is one of the most ecologically diverse countries, with four different geographical and climate zones. The western parts of the country boast the high Andes - the mountain range that stretches throughout the entire South America; in the middle, there are lowlands called llanos; further south is the Amazonian jungle, and in the southeastern portion of Venezuela, there is the country's most extensive region, known as the Guayanas, with its mountains that are oldest range in the world, formed millions of years ago. Here, where the borders of Venezuela, Brazil, and Guyana meet, the majestic range of table mountains (called tepuis) towers over the region of Gran Sabana, populated mainly by the Pemon people. It is one of those magical places on Earth that is a must-see. Another such miracle of nature located in this region is the highest waterfall in the world - Salto Angel. And in Mérida, situated at the foot of the Andes, there is a mountain cable car that can take you up the mountain of Pico Espejo (4,765 meters above sea level), from whose peak you can admire the highest mountain of Venezuela Pico Bolivar (4,978 meters above sea level) - covered by eternal snow and glaciers. It is the highest-reaching cableway in the world.

Venezuela has tremendous tourism potential, which is - unfortunately - barely used today, mainly due to the lack of adequate infrastructure. Successive governments have focused primarily on the exploration of oil, making the development of the country dependent on it.

Certainly, the musical talents of Venezuelans are an acknowledged - and used - potential. The system of Youth and Children Orchestras and Symphony Choirs, produced excellent results in the first decade of the 21 st century thanks to the genius of its creator - maestro José Antonio Abreu. With 300 thousand children and young people within the orchestra system, Venezuela has become a classical music superpower, and the younger generation flagship conductor, Gustavo Dudamel, is one of the greatest contemporary masters of the baton.

I have proudly noted that a significant contribution to the development of the system has been made by Polish artists. In the 1970s in Maracaibo, the capital of the Zulia State (north-western part of the country) a group of more than 20 Polish musicians settled, many of whom contributed to laying the foundations of the system. Bogdan Trochanowski, Wojciech Gałązka, and Marek Gajzler - are the names of only some of them.

For the researchers of the history of Latin America, Venezuela is an important country for yet another reason - it was the home of Simón Bolívar, the great liberator (Libertador) of Latin America, a hero of the independence struggle in the first half of the nineteenth century. Venezuelans honor his memory at every turn. There is probably no city in this country, where the main square is not named after Simón Bolívar; 
there is probably no public building where the main room is not named after him. $\mathrm{He}$ is revered almost as a divine entity, which is best evidenced by the very solemn protocol ceremony which accompanies the laying of wreaths at the mausoleum of Bolívar by the successive ambassadors accredited to Venezuela. Regardless of their political colors, many Venezuelan politicians have sought to monopolize Bolívar, presenting him as their ideological patron. The "Bolivarian Revolution" is yet another attempt to implement Bolivar's utopia, or perhaps his dream of a great country of universal prosperity - which is what I wish for my Venezuelan Friends.

I strongly encourage you to read this volume of Politeja and to learn something more about Venezuela. I would also like to take this opportunity to congratulate the Dean of the Faculty of International and Political Studies at the Jagiellonian University, Professor Bogdan Szlachta, Ms. Anna Kaganiec-Kamieńska, Assistant Professor at the Department of Latin American Studies of that same Faculty, on the initiative and the idea for this volume.

Krzysztof Jacek HINZ born on December 1st, 1955; diplomat, journalist, translator, specialist in Hispanic studies, correspondent for the Polish Press Agency to Cuba and Mexico (1991-1997), Ambassador of the Republic of Poland to Brazil (2001-2005) and Venezuela (2007-2012). 